\title{
Post-Training Evaluation on the Training of Basic Obstatric and Neonatal Emergency Service Training
}

\author{
Eva Kartikasari ${ }^{1}$, Siti Nurchasanah ${ }^{2}$, Wardoyo $^{3}$ \\ \{evakartikasari.mgl@gmail.com ${ }^{1}$,st.nurchdalmut@gmail.com², doybapelkessalaman@gmail.com ${ }^{3}$ \} \\ Quality Control Unit of the Semarang Health Training Center (Bapelkes) 1,2,3
}

\begin{abstract}
PONED Training is an effort to decrease Mother and Infant Mortality Rate in Central Java which the effectiveness was assessed through post-training evaluation. The aim was to describe the implementation of the training at the workplace. The study used mixed method with concurrent triangulation strategy. Subjects of the study were the participants of the training in 2014 from 10 health centers selected by purposive sampling. The results showed that the average knowledge of the respondents about the training material was approximately 79.5; Respondents' compliance in applying skills of preparation for obstetric-neonatal emergency was $96.3 \%$ while skills of stabilization, referral, and transportation of newborns were $25 \%$. Respondents were mostly proficient in handling cases of post partum hemorrhage and hypertension-pre eclampsia $(90,9 \%)$, while the cases of hyperbilirunemia were the less controllable $(27.3 \%)$; The implication of the study was to provide information whether the training was beneficial or not and to design better training.
\end{abstract}

Keywords: Evaluation; Post-Training Evaluation, PONED

\section{Introduction}

The Maternal Mortality Rate (MMR) in Indonesia is still high at 359/100,000 KH and the Infant Mortality Rate (IMR) reached $32 / 1000 \mathrm{KH}$ [1], in health problem areas (DBK) including remote areas, borders and islands (DTPK) which was not affordable by health workers and adequate health facilities. Likewise, MMR in Central Java Province from the data of the Central Java Provincial Health Office in 2014 continued to increase. In 2013 there were 668 cases, 2012 (675 cases), 2011 (668 cases), and 611 cases of maternal deaths occurred in 2010. "The highest maternal mortality rate occurred in Brebes Regency with 73 cases, followed by Tegal with 47 cases, Grobogan 43 cases, Pemalang 40 cases, and Pekalongan 39 cases"[2]. One of the efforts to reduce MMR and IMR, the government announced in the 2010-2015 Strategic Plan of the Ministry of Health stipulating that all District Health Centers in Indonesia must provide Basic Obstetric Neonatal Emergency Services (PONED) for 24 hours.

The implementation of PONED based on data from Bappenas [3] had some problems, such as maternal and neonatal complications just passing through in the clinic to get a referral to a hospital, midwife or village midwife much that refer directly to the Hospitals (mainly to private services) without going through health centers, including the PONED, the officers or health centers teams that had been trained by PONED did not have enough confidence to handle cases that should be able to be handled or at least did first aid before being sent to the hospital for various reasons. The data was in line with the results of a study from Kismoyo [4] 
that the condition of unavailable doctors in the service area made midwives were not confident in providing emergency care. the other factor was the unoptimal PONED in reducing MMR and IMR, also reported from the study of Surahwardy [5], government regulation in PONED service assistance and monitoring had not been maximized so that the ability of trained PONED teams could not be used optimally.

In 2014, Health Training Center (Bapelkes) of Semarang has provided training for PONED health centers team in Central Java. Bapelkes Semarang also has an obligation to evaluate the effectiveness of the training through post-training evaluation. It is an evaluation conducted to see how far the changes in mental attitude, improvement of knowledge, and or the addition of participants' skills have a direct influence on the performance of participants when returning to their own work environment [6].

\section{Method}

The mix method data collection was applying concurrent triangulation strategy, mixing two data when researchers compare one data source with another data source [7]. The locations of this study were in 10 (ten) health centers which had the alumni of PONED 2014 training participants in Semarang City, Wonogiri, Jepara, Batang, Pekalongan, Brebes, Blora, Purworejo and Wonosobo Districts. The research was conducted in March to May 2015.

There were 3 (three) evaluation variables. They were the knowledge of respondents after training; respondents' attitudes towards PONED training and respondents' skills in applying the training results. The quantitative data source was the alumni of PONED training participants that had three people at every health center, with details of doctors, nurses and midwives. The research sample was based on inclusion criteria.In the end, the researcher obtained 10 PONED health centers and got the respondents amounted to 30 participants and 2 (two) health centers as respondents to the instrument trial.

The source of the qualitative data was interviewes with the head of the health centers, colleagues who are involved in the PONED activities, that were the Head of the Administration Section, Midwives, Nurses, Laboratory and Pharmacy Analysts. The techniques for collecting quantitative data through questionnaires and knowledge tests while the qualitative data through interviews with superiors and PONED support teams, the observation to the training participants alumni, and documents.

The quantitative data were analysed by using SPSS 16.0 with steps to analyze the numbers descriptively and inferentially to achieve the "first" aim of this study, as follows; to find out the "effectiveness level" of PONED training using a "training effectiveness" analytical approach. The stages of data analysis to determine the effectiveness of a training according to Noe [7] were through several stages, determine the "score" for each respondents' answer in assessing every aspect of the measurement approach; calculate the "total score" and the "average score" for each aspect of the measurement approach; calculate "aspect value (NA)"; and decision making. The technique of analyzing data in the qualitative research approach was by interpreting the obtained results at the research place with the following stages of data transcripts; data reduction; presentation of data; and final conclusion. 


\section{Result and Discussion}

\subsection{Characteristics of Respondents}

There were 22 EPP respondents out of the 24 initial respondents consisting of doctors, midwives and nurses. The majority of respondents were $86.4 \%$ female, and $63.6 \%$ were $31-40$ years old. The number of bachelors (45.5\%) and Diploma (36.4\%). The respondents worked as PONED officers for 1-3 years, which was $45.5 \%$.

\subsection{Results of Post Training Evaluation (EPP) for Training Participant Alumni}

Post-Training of Respondents' Knowledge Evaluation. The post test value (88.0) was higher than the pre test (71.0) during the training, while the value at EPP was slightly lower than the post test value (79.5). The increase from pre to post test occurred because the assessment was carried out before and after the training, while the decrease in the EPP posttest occurred because the length of time from the training was quite long, which was about 1 year.

Respondents' Attitudes in Implementing Training Outcome Skills. The skills that was often applied was the skill for preparing obstetric-neonatal emergency service, amounted to $96.3 \%$ while the skill that lack of application was Stabilization, referral, and transportation of newborns, as much as $25 \%$. All respondents reported to the Head of health centers and socialized the results of the training at the workplace to the PONED Support Team. 77.3\% of respondents socialized less than one month after the training, and $81.8 \%$ socialized the results of the training to more than 5 friends at the health centers. Respondents who reported directly the results of training to the DHO were $59.1 \%$, and the rest were reported to the Head of the health centers. The training alumni who inventoried and suggested improvements in their institution in giving addition or improvement of PONED human resources was amounted to 86.4\%, 95.5\% improvement of PONED facilities and pre facilities, and also system improvements, procedures related to PONED services was 100\%. Respondents who carried out all the other follow-up plans that had been made during the training were $86.4 \%$.

Skills in Handling Obstetric-Neonatal Cases. The skills of the PONED trainees who were evaluated in the first indicator were about the mastery of skills in handling the cases that mostly dominated by respondents $(90.9 \%)$ were the cases of post partum bleeding and the cases of hypertension-pre Exlampsia. While the case of hyperbilirunemia was the most less mastered by respondents $(27.3 \%)$. The percentage of successful obstetric-neonatal treatment after the PONED training as a second indicator showed that in each of the PONED in public health center, most of them were referred. Some cases were unsuccessful and died. The most referring $\mathrm{c}$ was in Brebes Regency as many as 87.1, while the public health center that handled the most cases was in Pekalongan City as many as 61.2. The third indicator related to the types of cases that were successfully treated until the patient returned was BBL asphyxia cases which reached $97 \%$, while the definite cases referred were neonatal infection, hypoglycemia and hypothermia because these cases were not under the authority of the public health center. The last indicator evaluated on the PONED of the public health center referral network had running well, $16.5 \%$ of patients were referral from nearby health facilities such as the Midwife Independent Practice (BPM) and others. In addition to receiving referrals from the 
surrounding health facilities, the PONED of public health center also referred back to the surrounding health facilities and received referrals from the PONEK in Hospital.

\section{Supporting and inhibiting factors for the application of the PONED training results.}

Table 1. Policy as Supporting and Inhibiting Factors For The Application of The PONED Training Results

\begin{tabular}{ll}
\hline \multicolumn{1}{c}{ SUPPORTING FACTORS } & \multicolumn{1}{c}{ INHIBITING FACTORS } \\
\hline $\begin{array}{l}\text { Determination of the decision letter of the } \\
\text { PONED Team and the PONED Support Team. }\end{array}$ & $\begin{array}{l}\text { The referral system was not running optimally, } \\
\text { BPJS patients are difficult to be referred. } \\
\text { The standard operational of the action already } \\
\text { exists along with the Self Assessment form, } \\
\text { but the revision was done before the } \\
\text { accreditation of the public health center. }\end{array}$ \\
$\begin{array}{l}\text { Regular meeting forum for traditional birth } \\
\text { attendants (monthly). }\end{array}$ \\
The provision of mandatory delivery at the \\
health center, especially during working hours \\
Patient referral was accompanied by officers \\
and stabilized according to Standard \\
operational. \\
Increasing the collaboration with visiting to the \\
center of statistic department (BPS). \\
Collaborating partners / sectors include the \\
sub-district, FKD, FRK (Forum for Refreshing \\
Cadres) which guided by doctors, nurses, \\
midwives and nutrition workers
\end{tabular}

Supporting factors for the application of the PONED training results was one component in achieving success in the implementation of the PONED in public health center. One of them was by establishing a PONED Decree from the Regent as a legal basis that strengthens the implementation of PONED. Likewise, about what happened in Brebes district in the research on the Implementation of the Basic Emergency Obstetric and Neonatal Service System (PONED) in the Sitanggal Health Center in Brebes Regency had been supported by the determination of the PONED decision letter from the regent namely the Brebes Regent Decree Number 050/488 of 2015 concerning Determination the ability of the public health center as Basic Emergency Obstetrics and Neonatal Services (PONED) in Brebes Regency and Decree on the determination of the core PONED team from the head of the health service namely Decree of the Head of Brebes Regency Office Number 800.2 / 8734 Year 2015 Regarding the Establishment of a public health center Implementing Core Team who were Capable in Obstetrics and Basic Emergency Neonatal Services (PONED) ) [8].

The inhibiting factor in implementing the results of the PONED training for trainees was the referral system which had not been able to run optimally due to policies that block the PONED referral system. This condition was not only a problem in Central Java, the Northern Territory of Aceh Province had also experienced the same problem in terms of the referral system, human resources and referral targeting facilities to be one of the obstacles in organizing the success of PONED health center referral to PONEK [9]. 
Table 2. Human Resources (HR) as Supporting and Inhibiting Factors or The Application of The PONED Training Results

\begin{tabular}{ll}
\hline \multicolumn{1}{c}{ SUPPORTING FACTORS } & \multicolumn{1}{c}{ INHIBITING FACTORS } \\
\hline $\begin{array}{l}\text { The PONED Team and the PONED Support } \\
\text { Team understand enough of the duties and }\end{array}$ & Human Resources / Team PONED still lacking. \\
functions. & \\
$\begin{array}{l}\text { Official shift system. Complete morning service, } \\
\text { day and night service of } 2 \text { midwives }\end{array}$ & $\begin{array}{l}\text { Most of the skills are not applied because there } \\
\text { were no cases. }\end{array}$ \\
$\begin{array}{l}\text { Human Resources Management, The division of } \\
\text { the shift was considered in balanced expertise }\end{array}$ & $\begin{array}{l}\text { Lack of confidence in applying skills, even } \\
\text { though in theory they understand. }\end{array}$ \\
\hline
\end{tabular}

Human Resources were as another supporting component in the implementation of quality PONED in public health center. The presence of sufficient number of human resources and a balanced distribution of work shifts determines the quality of services provided to patients. In line with the results of research at the PONED Oesao Kupang Health Center that there was a significant influence from the aspect of human resources on the quality of neonatal services [10]. Adequate and professional human resources determine the success in saving patients. PONED of public health center in Bandung city was one of the puskesmas with a "Staffing" indicator that was categorized as weak so there needed to be a review of the number of staff and workload so that the quality of PONED public health center services could be optimal [11].

Human Resources competency was also one of the supporting components for the successful implementation of the post-training PONED health center. The competency of PONED participant in the Karawang district was not yet sufficient so that some authority was given in the administration of the PONED health center. This condition becomes one of the evaluation materials for training providers in determining the next PONED training policy [12].

Table 3. Infrastructure as Supporting and Inhibiting Factors for The Application of The PONED Training Results

\begin{tabular}{ll}
\hline \multicolumn{1}{c}{ SUPPORTING FACTORS } & \multicolumn{1}{c}{ INHIBITING FACTORS } \\
\hline Medicine was quite complete. & $\begin{array}{l}\text { The delivery room was in one room with the } \\
\text { puerperium } \\
\text { Health equipment and medicines: quite } \\
\text { complete, but incubators did not yet exist. }\end{array}$ \\
$\begin{array}{l}\text { Operational standard action already exists along } \\
\text { completeness of data: Map of the work area }\end{array}$ & \\
\hline
\end{tabular}

The availability and adequacy of PONED tools and medicines at the public health center was also a supporting factor for former PONED trainees in applying the results of the training in their work environment. This condition was in accordance with the results of the PONED health center research in the Java-Bali region which was said to have better readiness compared to other regional health centers in PONED services including thse availability and adequacy of PONED tools and medicines [13]. 


\subsection{Post-Training Evaluation Results (EPP) of Respondents (Triangulation)}

PONED Support Team. The PONED support team consisted of doctors, midwives, nurses, health analysts, administrative staff and others who were given questionnaires. Data obtained by $97 \%$ of the PONED support teams have received information and $95 \%$ of the teams had worked in accordance with the Standard Operational. The PONED support teams by $61 \%$ had not received decision letters related to PONED and $68 \%$ had never gained competency by apprenticeship at PONED Hospital.

Alumni of the Head of Public Health center. Post training evaluation conducted on alumni superiors of the public health center obtained data that $83 \%$ of public health center had been used for PONED; the majority of public health center also collaborated across sectors to support PONED at $63 \%$. Coaching had also been carried out both from the Health Office and from the district hospital in supporting PONED, the Health Office provides guidance to the majority of health centers, there were $62 \%$ and $41 \%$ of hospitals. Cross-sectoral cooperation in Central Java had a big role in supporting the implementation of PONED in public health center. The high percentage of cross-sector support was one of the factor for the achievement of maternal and child mortality in Central Java with the presence of a PONED in public health center. Not all regions have cross-sector supports, the results of the analysis of the implementation of the PONED program in Depok City still need to optimize partnerships with various sectors in an effort to accelerate the reduction of maternal mortality [14]. Support and participation from cross-sectoral as PONED implementation partners turned out had a big role in efforts to reduce maternal and child mortality[15].

\section{Public Health Office}

Table 4. Public Health Office Result

\begin{tabular}{|c|c|}
\hline POLICY & GUIDANCE \\
\hline $\begin{array}{l}\text { PONED Public health center decision letter. } \\
\text { All birth are performed at the PONED in public health center. } \\
\text { Every pregnant woman is controlled at least once by a doctor. } \\
\text { Supervision of Obsgyn specialists at once a year in each } \\
\text { district. } \\
\text { Guidance of health centers by the health services at once a } \\
\text { year, Technical guidance by the field of public health } \\
\text { development (Kesga } 2 \mathrm{x} \text { a year) } \\
\text { Procurement of facilities and infrastructure from the } \\
\text { Department of health and the regional budget } \\
\text { The implementation of PONED uses national-level of } \\
\text { standard operation. } \\
\text { The AMP policy has been carried out since } 2010 \text {. If there is a } \\
\text { case, an assessment is done by a team consisting of SPOG, } \\
\text { Pediatricians, SPOG doctors, Midwives, Nurses. }\end{array}$ & $\begin{array}{l}\text { HR development in the form of } \\
\text { training: umbilical infusion } \\
\text { The use of equipment that never be } \\
\text { used.s }\end{array}$ \\
\hline
\end{tabular}


The support and participation of the Health department as a core and controller of the quality of PONED in public health services is a vital part. The implementation of the PONED in public health services in Bangetayu had not been fully effective due to the lack of support from the Health department [16]. Support from the Health department in the form of improving the quality of human resources, fulfilling infrastructure facilities, giving awards, assisting and evaluating were one of the success factors of the PONED program at the designated health centers. The lack of supervision by the Health Office Department for the PONED program was also still found in Karang Malang Public Health Center Semarang [17]. Most supervision was carried out at the beginning and middle of the semester but not yet focused on the implementation of the PONED program.

PONEK Hospital. Based on the eight public health center of EPP respondent, only 4 PONEK hospitals were used as data collection respondents, this was due to various limitations, with the following results:

Table 5. Public Health Office Result

\begin{tabular}{|c|c|}
\hline ADVANTAGES & DISADVANTAGES \\
\hline $\begin{array}{l}\text { The PONED in public health center refers by } \\
\text { using the appropriate documents but some of } \\
\text { them do not use standard forms yet; accompanied } \\
\text { by a midwife; and before referring, } \\
\text { communication via telephone with the PONEK in } \\
\text { Hospital is a must. } \\
\text { The PONED officer monitors the progress of his } \\
\text { referred patients, by visiting directly or by } \\
\text { telephone to the PONEK Hospital. } \\
\text { The guidance of PONEK in Hospital to PONED } \\
\text { Pin public health center is carried out routinely in } \\
\text { the form of technical guidance by obstetricians } \\
\text { and some pediatricians who come to the public } \\
\text { health center. Some have not been coaching } \\
\text { routinely because there is no clarity of duties / } \\
\text { authority from the District / City Health Office. } \\
\text { A Maternal Perinatal Audit (AMP) is always } \\
\text { carried out in a maternal or infant death, } \\
\text { involving all relevant parties. }\end{array}$ & $\begin{array}{l}\text { The PONED officer does not yet have sufficient } \\
\text { competence in determining the patients to be } \\
\text { referred and stabilizing the patients so that they } \\
\text { need to be improved } \\
\text { Not all PONED in public healths center use } \\
\text { PONEK Hospital as a place of internship for } \\
\text { PONED officers to improve their competence. }\end{array}$ \\
\hline
\end{tabular}

\section{Conclusion}

From the EPP results, it was concluded that the average value of respondents' knowledge about training material was estimated to be 79.5. The compliance of respondents in applying the skills of preparation for obstetric-neonatal emergency amounted to $96.3 \%$. Meanwhile, stabilization, referral, and transportation of newborns was $25 \%$. Skills for handling post 
partum hemorrhage cases and cases of Hypertension (Pre) Eclampsia was 90.9\%; case of hyperbilirunemia in the amount of $27.3 \%$.

Supported factors that influenced the implementation of the training results were regular meetings at the health centers through lokmin activities to discuss PONED cases and guidance from Public Health Office and RSUD. The inhibiting factors included incomplete facilities and equipment; lack of staff skills; only few patients that made the staff did not have many skills that could be practiced in PONED management 


\section{Reference}

[1] Kementerian Indonesia.: Survei Demografi dan Kesehatan Indonesia 2012. Jakarta: Kementerian Kesehatan. (2013).

[2] Nugroho, Sigit A. dan Dwi Royanto. Angka Kematian Ibu Melahirkan Tinggi, Jateng Buru Ibu Hamil. http://nasional.news.viva.co.id/news/read/609481-angka-kematian-ibu-melahirkan-tinggi-jateng-buru-ibu-hamil. (2015).

[3] Bapenas.: Ringkasan Peta Jalan Percepatan Pencapaian Tujuan Pembangunan Milenium di Indonesia. Hal 95-104. (2010)

[4] Kismoyo, Christina P, Mohammad Hakimi dan Mubasysyir Hasanbasri.: Benarkah Puskesmas PONED Efektif ?.Yogyakarta: Jurnal Kebijakan Kesehatan Indonesia (Vol. 1, No. 2): Hal 93-102. (2012).

[5] Surahwardy, A.: Evaluasi Pelaksanaan Pelayanan Obstetri Neonatal Emergensi Dasar (PONED) di Puskesmas Mamajang Kota Makassar. Tesis Pascasarjana UNHAS. Makassar. (2013).

[6] Muslimin.: Evaluasi Program Pendidikan dan Pelatihan Kepemimpinan Tingkat IV Pemerintah Provinsi Nusa Tenggara Barat. Jurnal Teknologi Pendidikan,vol. 18(1): 22-32. (2016).

[7] Noe, Raimond, A.: Manajemen Sumber Daya Manusia: Mencapai Kunggulan Bersaing, (Penerjemah David Wijaya). Jakarta: Salemba Empat. (2010).

[8] Valentina A.F.M.A, Anneke Suparwati, dan Antono Suryoputro. Analisis Pelaksanaan Sistem Pelayanan Obstetri dan Neonatal Emergensi Dasar (PONED) di Puskesmas Sitanggal Kabupaten Brebes. Jurnal Kesehatan Masyarakat (E-Journal). Volume 4, Pp.156-160. (2016)

[9] Jaya, Susanti Tria, Johanes C mose, Farid Husin, Jusuf $\mathbf{S}$ Effendi, dan Deny K Sunjaya.: Hubungan Sumber Daya Manusia, Sarana Prasarana, Komunikasi PONED-PONEK, dan Standar Operasional Prosedur dengan Syarat dan Persiapan Rujukan Puskesmas PONED. Jurnal Kesehatan Prima. Vol. 13, pp.41-50. (2019).

[10] Fai, Isterina F., David B.W. Pandie, dan Ina D. R. Ludji.: Manajemen Sumber Daya Terhadap Mutu Pelayanan Neonatus di Puskesmas PONED Oesao Kupang. Unnes Journal of Public Health. Vol.6, pp.87-91. (2017).

[11] Brahmana, Reisia Palmina, Kurnia Wahyudi, dan Lukman Hilfi.: Perspektif Tenaga Kesehatan: Budaya Keselamatan Pasien pada Puskesmas PONED di Kota Bandung. Jurnal Sistem Kesehatan. Vol. 3, pp.120-121. (2018).

[12] Susyanty, Andi Leny, Heny Lestary dan Raharni.: Pelaksanaan Program Pelayanan Obstetri dan Neonatal Emergensi Dasar (PONED) di Kabupaten Karawang. Buletin Penelitian Kesehatan, Vol. 44(40), pp.276. (2016).

[13] Mujiati, Heny Lestary, dan Eva Laelasari.: Kesiapan Puskesmas PONED (Pelayanan Obstetri Neonatal Emergensi Dasar) di Lima Regional Indonesia. Media Penelitian dan Pengembangan Kesehatan. Vol. 24(1), pp. 40. (2014).

[14] Handayani, Dyan dan Anhari Achadi.: Analisis Implementasi Program Pelayanan Obstetri Neonatal Emergensi Dasar (PONED) di Puskesmas Mampu Poned Kota Depok Tahun 2017. Jurnal Kebijakan Kesehatan Indonesia : JKKI. Vol.7, pp. 62. (2018).

[15] Hidayah, Luluk, Oktia Woro Kasmini Handayani,dan Dyah Rini Indriyanti.: Pelayanan Kesehatan Maternal dalam Akselerasi Penurunan Maternal Mortality. Public Health Perspective Journal. Vol. 1, pp.35-43. (2016).

[16] Susanti, Tri dan Aufarol Marom.: Evaluasi Program Puskesmas Mampu PONED (Pelayanan Obstetri Neonatal Emergensi Dasar) Di Puskesmas Bangetayu Semarang. Journal of Public Policy and Management Review. Vol. 8, pp.16. (2019).

[17] Desita, Usi Erna.: Evaluasi Pelaksanaan Pelayanan Obstetri dan Neonatal Emergensi Dasar (PONED) di Puskesmas Karang Malang Semarang. Jurnal Kesehatan Masyarakat. Vol. 1(2), pp.4-5. (2012). 